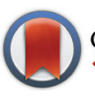

CrossMark

\& click for updates

Cite this: Food Funct., 2015, 6, 2017

\title{
Determination of the isoflavone composition and estrogenic activity of commercial dietary supplements based on soy or red clover
}

\author{
Susanne Andres, ${ }^{*} \dagger^{\mathrm{a}}$ Ulf Hansen, $\dot{\dagger}^{\mathrm{a}}$ Birgit Niemann, ${ }^{\mathrm{a}}$ Richard Palavinskas ${ }^{\mathrm{b}}$ and \\ Alfonso Lampen ${ }^{a}$
}

Dietary supplements high in isolated isoflavones are commercially available for human consumption primarily to alleviate menopausal symptoms in women. The isoflavone composition, quantity and importantly their estrogenic potency are poorly standardised and can vary considerably between different products. The aim of this study was to analyse the isoflavone composition of 11 dietary supplements based on soy or red clover using the HPLC/MS/MS technique. Furthermore, we investigated the transactivational potential of the supplements on the estrogen receptors (ER), ER $\alpha$ and $E R \beta$, performing luciferase reporter gene assays. As expected, we found that the isoflavone composition varies between different products. The measured total isoflavone contents in various supplements were mostly comparable to those claimed by the manufacturers in their product information. However expressing the isoflavone content as isoflavone aglycone equivalents, soy-based supplements had a clearly lower quantity compared to the manufacturer information. All supplements transactivated more or less ER $\alpha$ and ER $\beta$ with a preference for ER $\beta$. The transactivational efficiency exceeded partly the maximal $17 \beta$-estradiol induced ER activation. While the different soy-based supplements revealed similar transactivation potential to both ERs, red clover-based supplements differed considerably. We conclude that different commercial dietary supplements based on soy or red clover vary in their isoflavone composition and quantity. They are estrogenically active, although especially the red clover-based supplements show considerable differences in their estrogenic potential to ER $\alpha$ and ER $\beta$. Thus, different isoflavone-rich products cannot be necessarily compared regarding possible biological effects.

Received 24th March 2015, Accepted 8th May 2015

DOI: $10.1039 / \mathrm{c} 5 \mathrm{fo} 00308 \mathrm{c}$ www.rsc.org/foodfunction molecule is linked with sugar residues. ${ }^{6}$ Red clover contains predominantly the isoflavone aglycones biochanin A and formononetin, the methoxylated forms of genistein and daidzein, respectively, but other isoflavones such as genistein, daidzein, glycitein and prunetin were also identified (structures: Fig. 1). ${ }^{6-8}$

In contrast to Western populations, it is well-known that populations in Asia have a lower risk of developing certain diseases or disorders like cardiovascular diseases, menopausal disorders, osteoporosis or even cancer., ${ }^{9,10}$ Attention has been focused on their traditionally consumed soy-based nutrition including a high daily isoflavone intake of around 20 to $50 \mathrm{mg}$ as possible biologically-active plant ingredients. Western populations have usually only a daily intake of less than $3 \mathrm{mg}$ isoflavones. ${ }^{11}$

Numerous experiments and studies suggested possible health effects of isoflavones. Although there is no conclusive evidence for such benefits, ${ }^{12-15}$ there is great interest in increasing the isoflavone intake in Western populations with the promise of protecting against or mitigating certain dis-

\footnotetext{
${ }^{a}$ Department of Food Safety, Federal Institute for Risk Assessment, Max-Dohrn-Str 8-10, 10589 Berlin, Germany. E-mail: Susanne.Andres@bfr.bund.de

${ }^{b}$ Department of Safety in the Food Chain, Federal Institute for Risk Assessment,

Max-Dohrn-Str. 8-10, 10589 Berlin, Germany

$\dagger$ These authors contributed equally to this work.
} 
(a)<smiles>CC12CCC3c4ccc(O)cc4CCC3C1CCC2O</smiles>

(b)<smiles>[R4]c1ccc(-c2coc3cc([R3])c([R])c([R1])c3c2=O)cc1</smiles>

\begin{tabular}{lcccc}
\hline Isoflavone & $\mathrm{R} 1$ & $\mathrm{R} 2$ & $\mathrm{R} 3$ & $\mathrm{R} 4$ \\
\hline Aglycones: & & & & \\
Genistein & $\mathrm{OH}$ & $\mathrm{H}$ & $\mathrm{OH}$ & $\mathrm{OH}$ \\
Daidzein & $\mathrm{H}$ & $\mathrm{H}$ & $\mathrm{OH}$ & $\mathrm{OH}$ \\
Glycitein & $\mathrm{H}$ & $\mathrm{O}-\mathrm{CH}_{3}$ & $\mathrm{OH}$ & $\mathrm{OH}$ \\
Biochanin A & $\mathrm{OH}$ & $\mathrm{H}$ & $\mathrm{OH}$ & $\mathrm{O}-\mathrm{CH}_{3}$ \\
Formononetin & $\mathrm{H}$ & $\mathrm{H}$ & $\mathrm{OH}$ & $\mathrm{O}-\mathrm{CH}_{3}$ \\
Prunetin & $\mathrm{OH}$ & $\mathrm{H}$ & $\mathrm{O}-\mathrm{CH}_{3}$ & $\mathrm{OH}$ \\
Glycosides: & & & & \\
Genistin & $\mathrm{OH}$ & $\mathrm{H}$ & $\mathrm{O}-\mathrm{Glc}$ & $\mathrm{OH}$ \\
Daidzin & $\mathrm{H}$ & $\mathrm{H}$ & $\mathrm{O}-\mathrm{Glc}$ & $\mathrm{OH}$ \\
Glycitin & $\mathrm{H}$ & $\mathrm{O}-\mathrm{CH}_{3}$ & O-Glc & $\mathrm{OH}$
\end{tabular}

Fig. 1 Structures of $17 \beta$-estradiol (a) and isoflavones (b).

eases or disorders such as menopausal symptoms or osteoporosis. Thus, in particular peri- and postmenopausal women are the special target group for isoflavone-rich dietary supplements. In fact, consumers are overflowed with such over the counter supplements.

Available products contain mostly 40 to $50 \mathrm{mg}$ isoflavones per tablet; occasionally, they have a higher isoflavone content of up to 100 or even $200 \mathrm{mg}$ (cited by Mortensen et al. ${ }^{16}$ ). The real content of isoflavone-rich supplements is often not consistent with the isoflavone amount that is claimed by the manufacturers. ${ }^{17-21}$ Thus, the aim of our study was to determine the isoflavone composition of 11 soy- or red clover-based dietary supplements, available on the German market.

Besides the assumption of numerous beneficial health effects, research on isolated isoflavones also revealed potential adverse effects for instance on the reproductive system or even regarding possible tumour-promoting effects on estrogensensitive tissues such as the breast. Therefore, the safety of a long-term intake of isolated isoflavones at high doses has still to be elucidated especially for postmenopausal women. ${ }^{12,22-24}$

In particular, there are concerns due to the weakly estrogenic potential of isoflavones acting among others via the two estrogen receptors (ER), ER- $\alpha$ and ER- $\beta$. Activation of ER- $\alpha$ is associated with cell proliferation and with carcinogenicity in estrogen-sensitive tissues, while ER- $\beta$ has a particular role in suppressing estrogenic signal mechanisms stimulated by ER- $\alpha$. ER- $\beta$ negatively regulates cellular proliferation and plays a pro- tective role in normal breast tissue (reviewed by Andres et $a .^{23}$ ). Based on in vitro and xenograft animal studies, it is hypothesized that isoflavones may promote primarily ERmediated cell proliferation of estrogen-sensitive human cells at concentrations that are also present in the human plasma. ${ }^{23,25,26}$ However, isoflavones at low concentrations $(\leq 1$ $\mu \mathrm{M})$ induce only cell proliferation in cell lines with a predominance for ER- $\alpha$, while in cell lines expressing mainly ER- $\beta$ the cell growth is reduced by isoflavone incubation. ${ }^{27,28}$ The second aim of the present study was to determine the estrogenic activities of the 11 investigated isoflavone-rich supplements.

\section{Materials and methods}

\subsection{Reagents and standards}

HPLC grade solvents methanol and formic acid were purchased from Merck (Germany). All isoflavone standards were obtained from Sigma Aldrich (Germany). Medium and solvents for the cell culture and the luciferase reporter gene assay were purchased primarily from PAA Laboratories (Germany). Glycylglycin, $\mathrm{MgSO}_{4} \cdot 7 \mathrm{H}_{2} \mathrm{O}$ and Triton $\mathrm{X}-100$ were purchased from Sigma Aldrich and ethylene diamine tetraacetic acid and TrisAcetate from Serva (Germany).

\subsection{Samples and sample preparation}

Eighteen isoflavone-rich supplements based on soy or red clover, which were available on the German market, were investigated regarding their composition of nine isoflavones. Seven preparations could not be analysed due to their insolubilities. The remaining 11 products were capsules.

For isoflavone analysis, the capsule content (around 300 to $500 \mathrm{mg}$ ) was weighed and dissolved in $100 \mathrm{~mL}$ of $70 \%$ methanol resulting in isoflavone extraction as described by others. ${ }^{7,19}$ Four capsules of each supplement were analytically examined regarding their isoflavone composition. For the reporter gene assays, 10 capsules of each supplement were diluted in $25 \mathrm{~mL}$ of $70 \%$ methanol. Solutions were sonicated for $10 \mathrm{~min}$ and filtered several times through a filter with a pore size of $450 \mathrm{~nm}$ (Carl Roth $\mathrm{GmbH}$, Germany). The filtered solution was used for the isoflavone analysis as well as for the cell culture.

For analysis, a standard solution was prepared by dissolving the isoflavone standards in $70 \%$ methanol obtaining a stock solution with concentrations between 0.2 and $1.3 \mathrm{mM}$. Subsequently, this solution was diluted 1 to 10 times obtaining the standard solution with the following isoflavone concentrations: $89.6 \mu \mathrm{M}$ genistein, $88.9 \mu \mathrm{M}$ daidzein, $23.2 \mu \mathrm{M}$ glycitein, $21.0 \mu \mathrm{M}$ daidzin, $34.8 \mu \mathrm{M}$ glycitin, $127.0 \mu \mathrm{M}$ biochanin $\mathrm{A}$, $92.4 \mu \mathrm{M}$ formononetin and $72.9 \mu \mathrm{M}$ prunetin. Due to supply bottleneck of genistin, a separate genistin standard solution $(60.1 \mu \mathrm{M})$ was used for quantitative determination. Prior to the HPLC application, samples of the isoflavone supplements were further diluted 1:500 in 70\% methanol and the standard solution $1: 200$. All solutions were stored at $7{ }^{\circ} \mathrm{C}$. 


\section{$2.3 \quad \mathrm{HPLC} / \mathrm{MS} / \mathrm{MS}$}

HPLC/MS/MS is a sensitive and specific method and has been used by other working groups for the analytical determination of isoflavones. $^{8,19}$ Ten $\mu \mathrm{L}$ of the substances were injected into the HPLC. The HPLC system used was a Shimadzu HPLC with an LC-10AD pump and an SIL-10AXL Autoinjector. HPLC separation was carried out with a Luna 3u C18 (2) column, $150 \mathrm{~mm} \times 2 \mathrm{~mm}$ (Phenomenex, Germany). As an HPLC eluent, $70 \%$ methanol was used isocratically with a flow rate of $0.2 \mathrm{~mL}$ $\min ^{-1}$. Table 1 shows the retention time of each isoflavone molecule.

The isoflavones were separated according to their molecular mass with a tandem mass spectrometer. MS separation was carried out with an AB Sciex API 2000 Triple-Quadrupol mass spectrometer (AB Sciex, Germany) using the MRM (Multiple Reaction Monitoring) modus. For the positive ionization, an ion spray voltage of $6000 \mathrm{~V}$ was used. Fragmentation was

Table 1 HPLC retention times of the isoflavone molecules as well as the masses of the main ions and their fragmentation products and the corresponding collision energies of the fragmentation products for MS analytics

\begin{tabular}{|c|c|c|c|}
\hline Isoflavones & $\begin{array}{l}\text { HPLC retention } \\
\text { time (min) }\end{array}$ & $\begin{array}{l}\text { Ion mass } \\
\text { (Da) }\end{array}$ & $\begin{array}{l}\text { Collision energy } \\
(\mathrm{eV})\end{array}$ \\
\hline \multirow[t]{4}{*}{ Genistein } & \multirow[t]{4}{*}{3.19} & $270.99^{a}$ & \\
\hline & & 91.0 & 51 \\
\hline & & 153.0 & 39 \\
\hline & & 65.0 & 69 \\
\hline \multirow[t]{4}{*}{ Genistin } & \multirow[t]{4}{*}{1.96} & $433.08^{a}$ & \\
\hline & & 271.1 & 25 \\
\hline & & 91.1 & 83 \\
\hline & & 153.2 & 69 \\
\hline \multirow{4}{*}{ Daidzein } & \multirow{4}{*}{2.7} & $254.96^{a}$ & \\
\hline & & 91.1 & 51 \\
\hline & & 65.1 & 73 \\
\hline & & 137.2 & 31 \\
\hline \multirow[t]{4}{*}{ Daidzin } & \multirow[t]{4}{*}{1.9} & $417.01^{a}$ & \\
\hline & & 255.0 & 23 \\
\hline & & 91.1 & 87 \\
\hline & & 199.1 & 57 \\
\hline \multirow[t]{4}{*}{ Glycitein } & \multirow[t]{4}{*}{6.19} & $285.02^{a}$ & \\
\hline & & 270.1 & 35 \\
\hline & & 242.1 & 43 \\
\hline & & 118.0 & 57 \\
\hline \multirow[t]{4}{*}{ Glycitin } & \multirow[t]{4}{*}{1.84} & $446.99^{a}$ & \\
\hline & & 285.0 & 27 \\
\hline & & 270.1 & 53 \\
\hline & & 242.2 & 67 \\
\hline \multirow[t]{4}{*}{ Biochanin A } & \multirow[t]{4}{*}{6.17} & $285.01^{a}$ & \\
\hline & & 152.0 & 37 \\
\hline & & 213.0 & 49 \\
\hline & & 89.0 & 83 \\
\hline \multirow{4}{*}{ Formononetin } & \multirow[t]{4}{*}{4.37} & $269.09^{a}$ & \\
\hline & & 197.2 & 51 \\
\hline & & 89.0 & 81 \\
\hline & & 90.0 & 67 \\
\hline \multirow[t]{4}{*}{ Prunetin } & \multirow[t]{4}{*}{5.64} & $285.01^{a}$ & \\
\hline & & 91.0 & 53 \\
\hline & & 167.0 & 39 \\
\hline & & 242.1 & 43 \\
\hline
\end{tabular}

${ }^{a}$ Main ion.
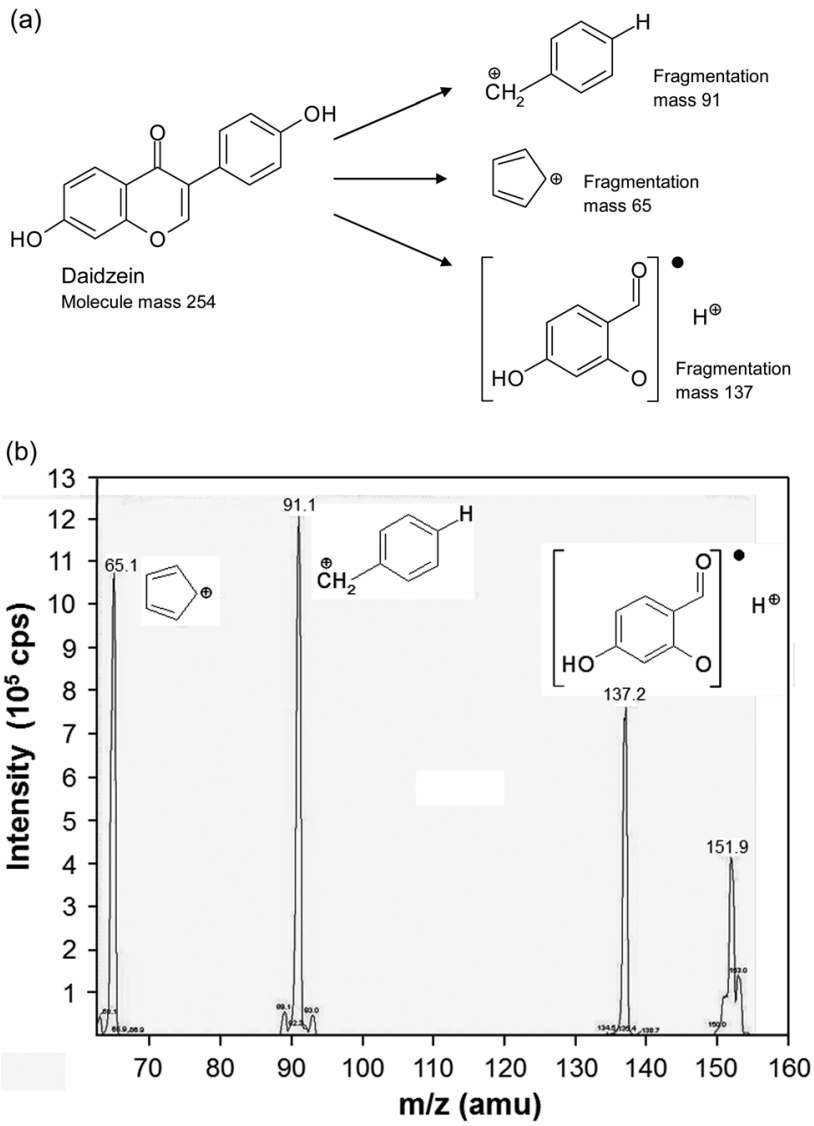

Fig. 2 Fragmentation (a) and chromatogram (b) of daidzein. (b) shows the mass spectrum of daidzein with its major fragments at $\mathrm{m} / \mathrm{z} 65.1,91.1$ and 137.2. Plotted is the intensity against the mass-to-charge ratio.

induced by CID (collision induced dissociation) with nitrogen as collision gas. The detection was carried out with a channel electron multiplier. Table 1 shows the masses of the main ions and their fragmentation products and the corresponding collision energies of the fragmentation products. The structural fragmentation and a representative chromatogram of daidzein are shown in Fig. 2. For the quantitative determination of the isoflavone content, calibration curves were plotted with each isoflavone standard. For the calibration curves, standard solutions were diluted from $1: 20$ to $1: 400$. The isoflavone quantity was calculated from the peak areas in the chromatogram of the supplements and the corresponding isoflavone calibration curve. The isoflavone content was expressed as the mean.

The accuracy of the system was tested using standard additions. Here, we prepared different solutions with specific concentrations of supplement S1 and the standard solution. The measured concentration was in accordance with $95 \%$ of the expected value.

\subsection{Luciferase reporter gene assay for the determination of ER activities}

To determine the estrogenic activity of the isoflavone-rich supplements, we performed reporter gene assays with Human 
Embryonic Kidney 293 cells (HEK293), which contain a stablytransfected full-length recombinant human ER $\alpha$ or ER $\beta$ construct $(\mathrm{HEK} 293 \mathrm{ER} \alpha / \beta)$. In addition, these cells contain the estrogen-responsive reporter gene construct 3xERE-tataLUC. The cells were kindly provided by Paul van der Saal and Bart van der Burg (Hubrecht Laboratory, Netherlands Institute for Developmental Biology). ${ }^{29}$

Cells were cultured in Dulbecco's Modified Eagle Medium (DMEM) with $4 \mathrm{mM}$ L-glutamine, 1\% penicillin/streptomycin solution, $1 \%$ non-essential amino acids and 10\% foetal calf serum in a humidified incubator at $37{ }^{\circ} \mathrm{C}$ and $5 \% \mathrm{CO}_{2}$. For the cell viability/luciferase reporter gene assay, cells were seeded in 96-well plates (Greiner bio-one, Germany) at a density of 20000 cells per well and allowed to attach for $48 \mathrm{~h}$. For dilutions of the test substances and the performance of the luciferase reporter gene assay, foetal calf serum was replaced in the medium with charcoal-stripped foetal calf serum (7.5\%). After medium replacement, the application of the test substances to the cells was carried out for $48 \mathrm{~h}$. The final solvent concentration (70\% methanol) in the culture medium was lower than $0.01 \%$. Subsequently, cell viability was determined using the CTB test (cell titer-blue, PAA Laboratories). Twenty $\mu \mathrm{L}$ CTB reagents were added to each well. After $2 \mathrm{~h}$, fluorescence was measured at $590 \mathrm{~nm}$ with a Mithras LD 940 microplate reader (Berthold, Germany).

After medium removal, cells were lysed with $75 \mu \mathrm{L}$ lyses buffer containing $0.1 \mathrm{M}$ TrisAcetate, $2 \mathrm{mM}$ ethylene diamine tetraacetic acid, 1\% Triton X-100 ( $\mathrm{pH} 7.5)$, frozen overnight at $-20{ }^{\circ} \mathrm{C}$ and thawed at room temperature on a plate shaker. Fifty $\mu$ l lysate were transferred in a white 96-well plate (Greiner bio-one). The samples were mixed automatically with $50 \mu \mathrm{L}$ luciferin-containing buffer $(20 \mathrm{mM})$ and $150 \mu \mathrm{l}$ assay buffer (25 mM glycylglycine, $15 \mathrm{mM} \mathrm{MgSO}, 4 \mathrm{mM}$ ethylene glycol tetraacetic acid, $1 \mathrm{mM}$ dithiothreitol, $1 \mathrm{mM}$ ATP, pH 7.8). Luminescence (luciferase activity) was measured with a Mithras LB 940 microplate luminometer (Berthold). Results were calculated in relation to the maximum ER activation induced by $\mathrm{E}_{2}$ at concentrations of $10^{-10}$ to $2 \times 10^{-9} \mathrm{M}$ which were set as $100 \%$. Sigmoidal dose-response curves were fitted with SigmaPlot software. All tests were performed as fourfold determination. Estrogenic activity was expressed as mean \pm SE.

\section{Results}

\subsection{Quantitative determination of isoflavone-rich dietary supplements}

We determined the quantity of nine isoflavones in 11 dietary supplements based on soy (numbering S1 to S6) or red clover (numbering S7 to S11). According to the manufacturer information, each capsule should contain 35 to $60 \mathrm{mg}$ isoflavones for supplements with soy extract and 40 to $80 \mathrm{mg}$ isoflavones for supplements with red clover extract (Table 2). Manufacturers recommend the intake of 1 or 2 capsules per day with 40 to $100 \mathrm{mg}$ isoflavones.
The isoflavone composition of the dietary supplements is shown in Table 2. Capsules had a real isoflavone content of around 32 to $80 \mathrm{mg}$ per capsule. The total isoflavone contents varied up to $22 \%$ between the 4 examined capsules per product. Soy-based supplements (S1-S6) contained primarily the glycosides genistin and daidzin as well as at lower amounts glycitin and the aglycones genistein and daidzein. Glycitein was only found in small amounts in S3 (0.07 mg per capsule). The soy-based products also contained the red clover isoflavone formononetin, but only in small amounts $(\leq 0.5 \mathrm{mg}$ per capsule). The typical red clover isoflavones, biochanin A and prunetin, were not found in the dietary supplements derived from soy.

Red clover-based products (S7-S11) contained, as expected, high amounts of formononetin and biochanin A, but also lower amounts of the other seven analysed isoflavone aglycones and glycosides. However, these seven isoflavones were not always present in the red clover-based supplements. For instance, supplement S7 did not contain genistin and glycitin, while the products S8 and S9 did not contain prunetin (Table 2).

The measured isoflavone content of all dietary supplements (with the exception of S1) was in good accordance with the isoflavone amount that was claimed by the manufacturer. The determined total isoflavone contents of the supplements correspond to 87 to $107 \%$ of the isoflavone contents that were given in the package inserts. The supplement S1 contained more than one third less isoflavones than the given manufacturer information (Fig. 3). According to the manufacturer information, the soy based supplements S1 as well as S4 to S6 should have a genistein/genistin content of $30 \mathrm{mg}$ per capsule. The greatest deviation from the real genistein/genistin content was in S1 with an almost $20 \mathrm{mg}$ lower amount per capsule (Table 2).

However, sugar residues of isoflavone glycosides account for about $40 \%$ of the molecular weight. Because of this it is more advisable to convert the isoflavone content to isoflavone aglycone equivalents (IAE). ${ }^{30}$ The calculated IAE values of the isoflavone-rich supplements are depicted in Fig. 3. Due to the high amount of isoflavone glycosides in the soy-based supplements, the IAE values were clearly lower than the total isoflavone amount and comprised only around 61 to $70 \%$ of the labelled isoflavone content (exception S1 with only around $43 \%$ ). Only the manufacturer of S2 gave the IAE value of $21.5 \mathrm{mg}$ with $10.85 \mathrm{mg}$ daidzein per capsule, while we calculated an IAE value of around $22.8 \mathrm{mg}$ with $16.5 \mathrm{mg}$ daidzein per capsule. The IAE values of red clover-based supplements were only marginally lower than the whole isoflavone amount due to their low content of isoflavone glycosides (Fig. 3).

\subsection{Determination of the estrogenic activity}

The isoflavone-rich supplements $\left(10^{-10}\right.$ to $\left.10^{-6} \mathrm{M}\right)$ as well as $\mathrm{E}_{2}\left(10^{-12}\right.$ and $\left.2 \times 10^{-9} \mathrm{M}\right)$ as the reference compound were analysed for their estrogenic potential. The $\mathrm{E}_{2}$ concentrations included circulating physiological $\mathrm{E}_{2}$ levels of premenopausal 


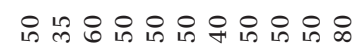

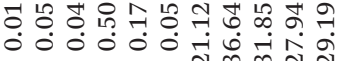

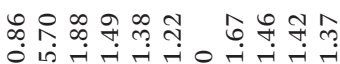

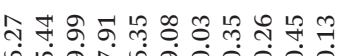

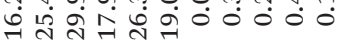

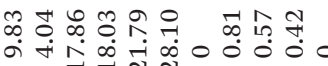

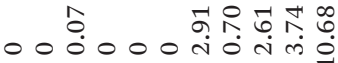

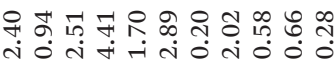

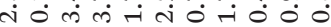

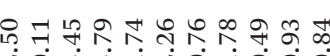

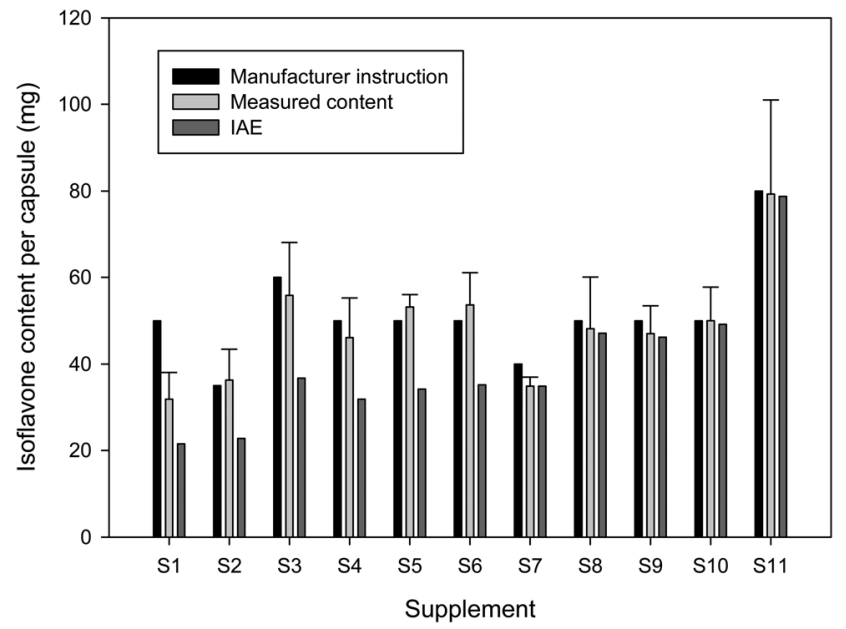

Fig. 3 Isoflavone content of dietary supplements derived from soy or red clover. The measured isoflavone content per capsule $(\mathrm{mg})$ of dietary supplements derived from soy (S1 to S6) or red clover (S7 to S11) was compared with the calculated IAE values and with the information given by the manufacturer. Only the manufacturer of the supplement S2 gave additional information about the IAE value of $21.5 \mathrm{mg}$ per capsule. This correlated quite well with our calculated IAE value of around $22.8 \mathrm{mg}$ per capsule.

women (about $10^{-9} \mathrm{M}$ ) and postmenopausal women (about $\left.10^{-11} \mathrm{M}\right) \cdot{ }^{31}$ Escande et al. noticed an overactivation of the luciferase reporter gene at a higher isoflavone concentration of $10^{-6} \mathrm{M}$, especially for genistein, daidzein and biochanin A in human cervix adenocarcinoma cells. ${ }^{32}$ Thus, luciferase expression analyses have to be performed with caution at such high isoflavone concentrations. Here, we used a maximum isoflavone concentration of $10^{-6} \mathrm{M}$. We examined also the cell cytotoxicity of our supplements with the CTB viability test. None of the supplements induced cytotoxic effects (data not shown).

The transactivation potential for both ERs of soy-based supplements was similar in spite of the different isoflavone compositions. For ER $\alpha$, the dietary supplements based on soy showed a likewise or higher transactivational efficiency compared to $\mathrm{E}_{2}\left(98-177 \%\right.$ S1-S6 vs. $\left.100 \% \mathrm{E}_{2}\right)$, while for $\mathrm{ER} \beta$ all supplements exceeded clearly the maximal $\mathrm{E}_{2}$-induced receptor activation $\left(142-211 \% \mathrm{~S} 1-\mathrm{S} 6\right.$ vs. $\left.100 \% \mathrm{E}_{2}\right)$. The soy-based supplements showed either an equal transactivational efficiency to both receptors or a higher efficiency to ER $\beta$ (Fig. 4 and Table 3).

In contrast to the supplements derived from soy, the red clover-based products differed considerably in their transactivational potential to ER $\alpha$ and ER $\beta$. Only the preparations S10 and S11 clearly exceeded the maximum $\mathrm{E}_{2}$-induced ER $\alpha$ activation by a factor of about 2.5 and 3 , respectively, while the other red clover supplements also transactivated ER $\alpha$ but to a minor or moderate extent (efficiencies $26-73 \%$ S7-S9 vs. $100 \%$ $\mathrm{E}_{2}$ ). For ER $\beta$ with the exception of S9 (efficiency 51\%), all red clover supplements exceeded the maximal $\mathrm{E}_{2}$-mediated $\mathrm{ER} \beta$ 

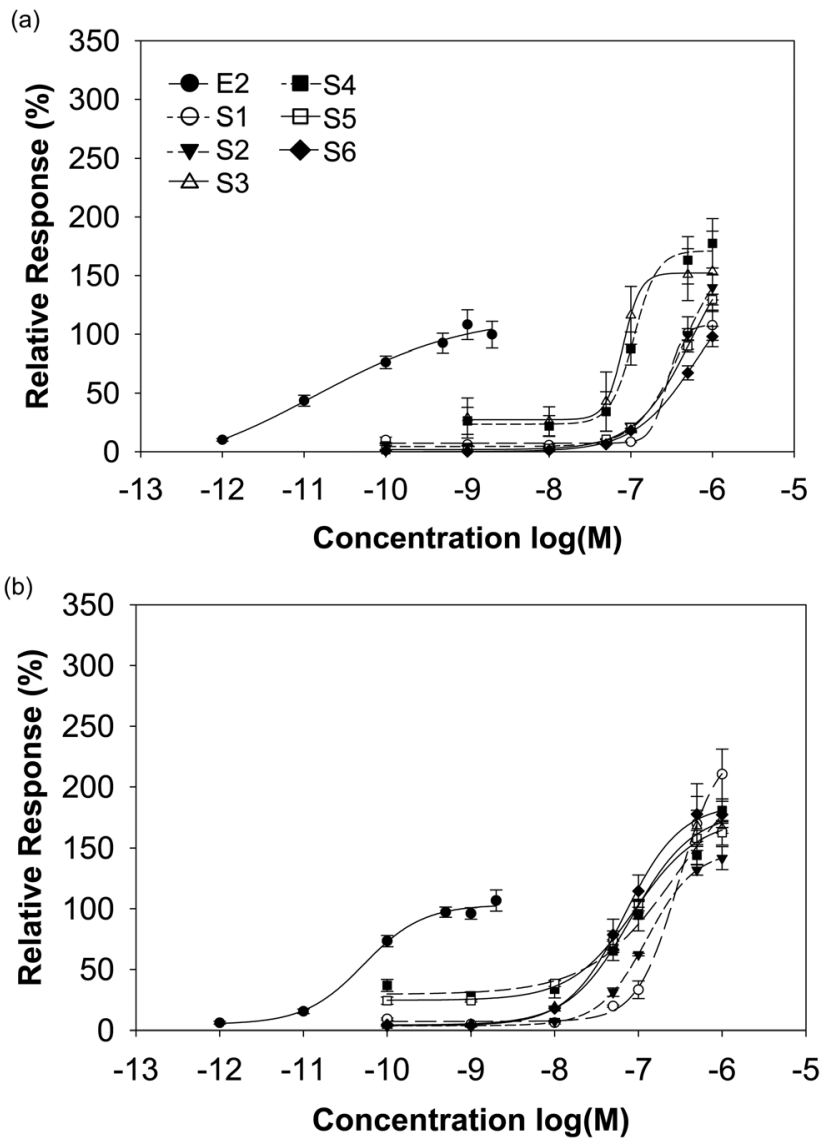

Fig. 4 Sigmoidal dose-response curves of ER activation for $E_{2}$ and soy based dietary supplements. Dose-dependent ER $\alpha$ (a) and ER $\beta$ (b) activation induced by $E_{2}$ and soy-based supplements was measured with luciferase reporter gene assays on ER transfected HEK293 cells.

activation (efficiencies 131-298\% $\quad \mathrm{S} 7 / 8 / 10 / 11$ vs. $100 \% \quad \mathrm{E}_{2}$ ). Some red clover-based supplements showed a better activation of $\operatorname{ER} \alpha$, others showed activation of $\operatorname{ER} \beta$ and again some others showed a similar activation of both ERs (Fig. 5 and Table 3).

For the determination of the potency for ER activation, we calculated the half maximal effective concentration $\left(\mathrm{EC}_{50}\right)$. However, we could not calculate $\mathrm{EC}_{50}$ values for all dietary supplements, because the maximum activation was not achieved in each case. Comparing the $\mathrm{EC}_{50}$ values of $\mathrm{E}_{2}$ (shown in Table 3) with those of the supplements, we could evaluate that the potency of the isoflavone-rich supplements was around 4000 to 16 000-fold less for ER $\alpha$ and 1000 to 3000-fold less for ER $\beta$.

The calculated estradiol equivalents (EEQ, calculation shown in Table 3) of the isoflavone-rich preparations, based on $\mathrm{EC}_{50}$ values of $\mathrm{E}_{2}$ and the supplements, ranged from 1.4 to $11.6 \mu \mathrm{g} \mathrm{E}_{2}$ per capsule for $\mathrm{ER} \alpha$ and 9.5 to $36.4 \mu \mathrm{g} \mathrm{E}_{2}$ per capsule for ER $\beta$. However only for the supplement S3, we could calculate EEQ values for both ER receptors with $7.6 \mu \mathrm{g} \mathrm{E}_{2}$ per capsule for $\mathrm{ER} \alpha$ and $24.2 \mu \mathrm{g} \mathrm{E}_{2}$ for $\mathrm{ER} \beta$ (Table 3).

\section{Discussion}

In the present study, we determined the isoflavone composition of 11 dietary supplements derived from soy (supplements S1-S6) or red clover (supplements S7-S11), available on the German market. These supplements are predominantly advertised for postmenopausal women for the alleviation of menopausal symptoms, although there is no conclusive evidence for the proposed health effects. ${ }^{24}$ In addition, these retail isoflavone products are only poorly standardised and lack reliable quality indicators. ${ }^{17}$ Therefore, it is well known that isoflavone-rich supplements can deviate significantly in their isoflavone content and composition from the manufacturer information. ${ }^{17-21}$

In our study, the investigated isoflavone-rich supplements should contain 35 to $80 \mathrm{mg}$ isoflavones per capsule. In contrast to numerous studies, the overall isoflavone contents from 9 of

Table $3 E_{50}$ and EEQ values of ER $\alpha$ or $E R \beta$ activation for isoflavone-rich supplements

\begin{tabular}{|c|c|c|c|c|c|c|c|c|c|}
\hline \multirow[b]{2}{*}{ Supplement } & \multicolumn{2}{|c|}{ Efficiency $^{a}(\%)$} & \multicolumn{2}{|l|}{$\mathrm{EC}_{50}{ }^{b, c}(\mathrm{M})$} & \multirow{2}{*}{$\begin{array}{l}n \text { ( } \mu \text { mol isoflavones } \\
\text { per capsule) }\end{array}$} & \multicolumn{2}{|c|}{$\begin{array}{l}\mathrm{EEQ}^{d}\left(\mathrm{nmol} \mathrm{E}_{2}\right. \\
\text { per capsule })\end{array}$} & \multicolumn{2}{|c|}{$\begin{array}{l}\text { EEQ }\left(\mu g \mathrm{E}_{2}\right. \\
\text { per capsule) }\end{array}$} \\
\hline & $\mathrm{ER} \alpha$ & $\operatorname{ER} \beta$ & $\mathrm{ER} \alpha$ & $\operatorname{ER} \beta$ & & $\mathrm{ER} \alpha$ & $\operatorname{ER} \beta$ & $\mathrm{ER} \alpha$ & $\mathrm{ER} \beta$ \\
\hline $\mathrm{S} 1$ & 108 & 211 & $2.5 \times 10^{-7}$ & n.d. ${ }^{e}$ & 82.5 & 5.2 & & 1.4 & \\
\hline $\mathrm{S} 2$ & 140 & 142 & n.d. & $1.3 \times 10^{-7}$ & 87.5 & & 34.8 & & 9.5 \\
\hline $\mathrm{S} 3$ & 154 & 166 & $7.9 \times 10^{-8}$ & $7.9 \times 10^{-8}$ & 140.6 & 28.5 & 88.7 & 7.6 & 24.2 \\
\hline $\mathrm{S} 4$ & 177 & 181 & $1.0 \times 10^{-7}$ & n.d. & 121.3 & 19.2 & & 5.2 & \\
\hline S5 & 129 & 163 & n.d. & $7.9 \times 10^{-8}$ & 130.5 & & 82.4 & & 22.4 \\
\hline S6 & 98 & 177 & n.d. & $5.0 \times 10^{-8}$ & 133.5 & & 133.5 & & 36.4 \\
\hline S7 & 26 & 148 & n.d. & $6.3 \times 10^{-8}$ & 127.3 & & 50.7 & & 13.8 \\
\hline S8 & 33 & 131 & n.d. & n.d. & 174.9 & & & & \\
\hline S9 & 73 & 51 & $5.0 \times 10^{-8}$ & n.d. & 169.7 & 42.6 & & 11.6 & \\
\hline S10 & 245 & 186 & n.d. & $7.9 \times 10^{-8}$ & 179.5 & & 56.8 & & 15.5 \\
\hline S11 & 298 & 298 & n.d. & n.d. & 283.4 & & & & \\
\hline
\end{tabular}


(a)

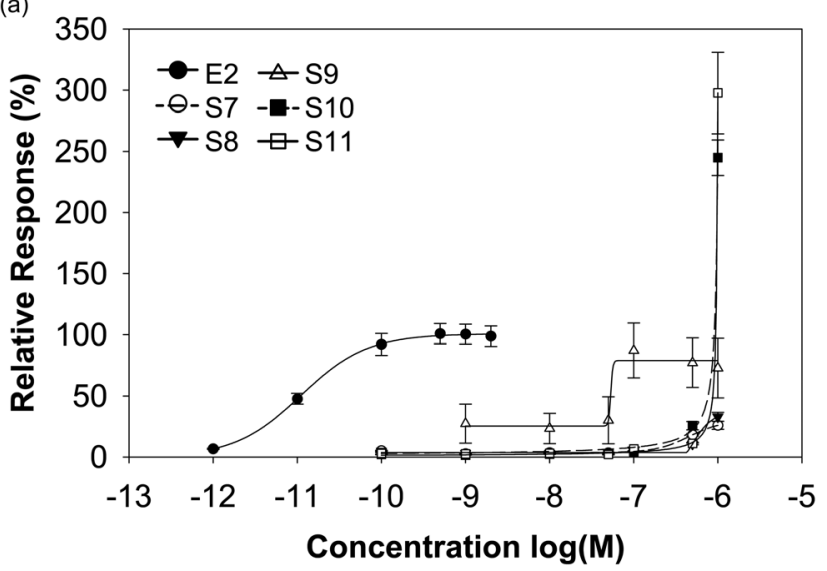

(b)

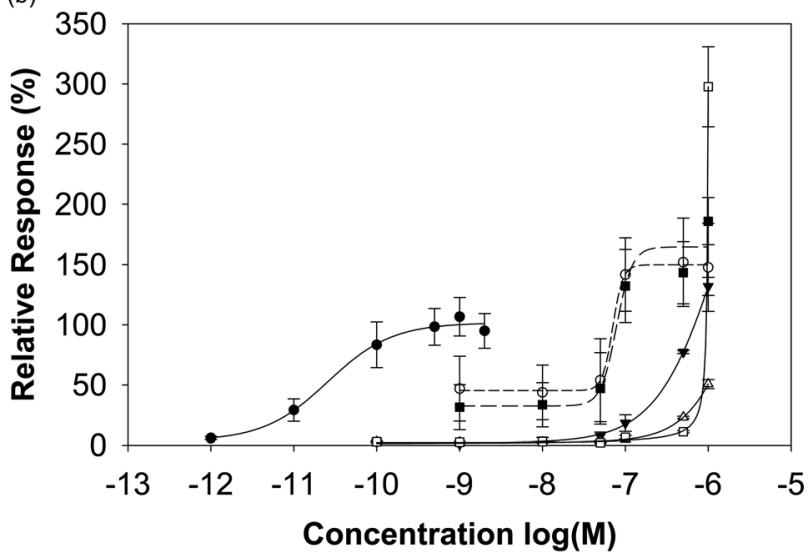

Fig. 5 Sigmoidal dose-response curves of ER activation for $E_{2}$ and red clover based dietary supplements. Dose-dependent ER $\alpha$ (a) and ER $\beta$ (b) activation induced by $E_{2}$ and red clover-based supplements was measured with luciferase reporter gene assays on ER transfected HEK293 cells.

11 of our test supplements were comparable to the manufacturer information (more than 90\% total isoflavones of the claimed isoflavone content). Similar results were obtained by Romani et $a .^{33}$ In a red clover-based supplement (S7) and a soy-based supplement (S1), we found an isoflavone content of $87 \%$ and $66 \%$, respectively, compared to the manufacturer information. The isoflavone content between different capsules of one product deviated up to $22 \%$. The supplements S1 and S4 to S6 have additional manufacturer information regarding the genistein/genistin content of $30 \mathrm{mg}$ per capsule. The greatest deviation from the mentioned genistein/genistin content was in $\mathrm{S} 1$ with only $11 \mathrm{mg}$.

These specifications refer to the total isoflavone content. It is well known that soy-based supplements contain primarily isoflavone glycosides. ${ }^{17}$ The sugar moiety of the isoflavone glycosides accounts for almost $40 \%$ of the molecular weight. Manufacturers should state the isoflavone content as IAE values reflecting the biological potency of their products for better consumer awareness and also for regulatory purposes. ${ }^{30}$ IAE values of the analysed soy-based supplements were only around 40 to $70 \%$ of the labelled isoflavone content. Only the manufacturer of S2 specified the IAE value of $21.5 \mathrm{mg}$ with $10.85 \mathrm{mg}$ daidzein per capsule. This correlated quite well with our calculated IAE value of around $22.8 \mathrm{mg}$ (16.5 mg daidzein) per capsule. As already described previously, the majority of red clover isoflavones are aglycones, ${ }^{7}$ because of that the IAE values of red clover-based supplements differed only marginally from the total isoflavone content.

Most soy-derived products contain a higher amount of genistein/genistin than daidzein/daidzin, ${ }^{4,17,33}$ but 4 of 6 investigated soy-based supplements contained higher amounts of daidzin than genistin. Interestingly, all the analysed soy-based products showed also small amounts of the typical red clover isoflavone, formononetin ( $\leq 0.5 \mathrm{mg}$ per capsule). As described previously, red clover-based supplements contained predominantly formononetin and biochanin A but also more or less the other seven scrutinised isoflavones. ${ }^{6-8}$

Isoflavones are able to bind weakly to and transactivate ER $\alpha$ or ER $\beta$ receptors showing a higher affinity to ER- $\beta .^{1}$ However, the binding and transactivation capacities differ between the various isoflavones. Genistein revealed the highest relative binding affinity followed by daidzein. Both isoflavones show good transactivational efficiencies to $\mathrm{ER} \alpha$ and $\operatorname{ER} \beta$ (72-85\%) compared to $\mathrm{E}_{2}(100 \%) .{ }^{31}$ The data about red clover isoflavones and their binding capacity to ER are not conclusive. Pfitscher et al. revealed low binding capacities of formononetin and biochanin $\mathrm{A},{ }^{34}$ while Kuiper et al. found no binding affinity of biochanin A and formononetin. ${ }^{2}$ However, genistein, daidzein, biochanin A and formononetin transactivated ER $\alpha$ and $\operatorname{ER} \beta$ in a yeast transactivation system with great variations of the potency and efficiency in ER activation. The transactivational efficiency varied for $\mathrm{ER} \alpha$ between only 14\% for daidzein and $107 \%$ for genistein $\left(E_{2}=100 \%\right)$ and for $\operatorname{ER} \beta$ between $77 \%$ for formononetin and $129 \%$ for daidzein $\left(\mathrm{E}_{2}=100 \%\right) .{ }^{5}$ Morito et al. revealed that the isoflavone glycosides genistin, daidzin and glycitin bind to and transactivate only poorly both ERs compared to their corresponding aglycones. ${ }^{35}$ However, human kidney tissues express $\beta$-glycosidases, which are able to cleave the sugar residues of isoflavone glycosides. ${ }^{36,37}$ Therefore, the human kidney HEK293 cell line, used in this study, may cleave the isoflavone glycosides to the probably more biologically active isoflavone aglycones.

The calculated potencies of our investigated isoflavone-rich supplements (several 1000-fold lower compared to $\mathrm{E}_{2}$ ) are in a similar range of the potencies of the single isoflavones genistein, daidzein, formononetin and biochanin as described previously. ${ }^{5}$ We found similar to earlier studies that the investigated isoflavone-rich supplements have a higher potency for ER $\beta$ than for ER $\alpha{ }^{1,5}$ However, the transactivational efficiencies of some of our soy- or red clover-based products exceeded clearly the maximum $\mathrm{E}_{2}$-mediated $\mathrm{ER} \alpha$ or $\operatorname{ER} \beta$ activation (e.g. up to a factor of 3 for S11), while previous studies found only a maximum transcriptional efficiency of around $130 \%$ with isolated isoflavones $\left(\mathrm{E}_{2}=100 \%\right) .{ }^{5}$ Although there are differences in the isoflavone composition of the analysed soy-based supplements, the estrogenic activities of both recep- 
tors were surprisingly similar, especially for ER $\beta$. In contrast, red clover-based supplements showed considerable differences in their ER activations. Supplement S11 revealed the highest ER activation for both receptors, while other supplements derived from red clover showed only minor or moderate activation potential. Besides formononetin and biochanin $\mathrm{A}$, the supplement S11 contained also a relatively high amount of glycitein compared to the other red clover-based supplements. However, whether glycitein caused the high activation potential could not be clarified in our study. It is known that isoflavone-rich supplements can also contain other unknown compounds or impurities, ${ }^{17,19}$ which may also have an impact on ER activation.

Based on the $\mathrm{EC}_{50}$ values for $\mathrm{ER} \alpha$ and $\mathrm{ER} \beta$ activation, we calculated EEQ values ranging from 1.4 to $11.6 \mu \mathrm{g} \mathrm{E}_{2}$ per capsule for $\mathrm{ER} \alpha$ and from 9.5 to $36.4 \mu \mathrm{g} \mathrm{E}_{2}$ per capsule for ER $\beta$. Similarly, Dornstauder et al. specified the transactivation capacity of a red clover extract corresponding to around $18 \mu \mathrm{g}$ $\mathrm{E}_{2}$ per $\mathrm{g}$ red clover extract for $\mathrm{ER} \alpha$ and $78 \mu \mathrm{g}$ for $\mathrm{ER} \beta .^{5} \mathrm{Behr}$ et al. analysed the estrogenic activity in foodstuff and found the highest activities with up to $1.5 \mu \mathrm{g}$ EEQ per $\mathrm{kg}$ in the traditional soy food tofu. ${ }^{38}$ For a better comparison, depending on the route of application an estradiol dose of 0.025 to $3 \mathrm{mg}$ per day can be applied during hormone therapy. ${ }^{39}$

Besides the assumption of numerous beneficial effects on health, concerns have arisen regarding possible adverse effects e.g. on tumour promotion of estrogen-sensitive tissues like the breast. Clear estrogenic potential of such dietary supplements could be verified in this study. The safety of a long-term intake of isolated isoflavones especially in high doses has still to be elucidated. ${ }^{12,24}$ For risk evaluation, the variance of the isoflavone composition and of the estrogenic potential between different isoflavone-rich supplements should be considered.

\section{Conclusions}

We found that isoflavone-rich supplements vary in their isoflavone composition and quantity. As expected, soy-based supplements contained primarily the isoflavone glycosides genistin and daidzin, while red clover-based supplements contained mainly the aglycones formononetin and biochanin A. The total isoflavone content measured was mostly comparable to that claimed by the manufacturers. However, the sugar residues of isoflavone glycosides contribute considerably to the molecular weight. Expressing the isoflavone content as IAE values, soy-based supplements had a clearly lower quantity than the manufacturer information. Therefore, manufacturers should state the isoflavone content as IAE values reflecting the biological potency of their products for better consumer awareness and also for regulatory purposes. All supplements transactivated more or less ER $\alpha$ and ER $\beta$ with a preferred potency to ER $\beta$. The transactivation efficiency of some preparations exceeded the maximum $\mathrm{E}_{2}$-induced $\mathrm{ER}$ activation. While the different soy-based supplements revealed similar transactivation potential to both ERs, red clover-based supple- ments differed considerably. For risk evaluation, isoflavone research (e.g. for clinical studies) and for consumers, the knowledge about the real isoflavone composition and quantity as well as about biological activities is required. One isoflavone-rich supplement is not necessarily comparable to another preparation.

\section{Abbreviations}

$\begin{array}{ll}\text { CTB } & \text { Cell titer-blue } \\ \mathrm{E}_{2} & 17 \beta \text {-Estradiol } \\ \text { EC }_{50} & \text { Half maximal effective concentration } \\ \text { EEQ } & \text { Estradiol equivalent concentration } \\ \text { ER } & \text { Estrogen receptor } \\ \text { HEK293 } & \text { Human embryonic kidney 293 cells } \\ \text { HPLC } & \text { High performance liquid chromatography } \\ \text { IAE } & \text { Isoflavone aglycone equivalents } \\ \text { MS/MS } & \text { Tandem mass spectrometry }\end{array}$

\section{Acknowledgements}

We thank Anja Köllner and Andreas Stock for technical support.

\section{References}

1 D. M. Harris, E. Besselink, S. M. Henning, V. L. Go and D. Heber, Exp. Biol. Med., 2005, 230, 558-568.

2 G. G. Kuiper, J. G. Lemmen, B. Carlsson, J. C. Corton, S. H. Safe, P. T. van der Saag, B. van der Burg and J. A. Gustafsson, Endocrinology, 1998, 139, 4252-4263.

3 W. Mazur, Baillieres Clin. Endocrinol. Metab., 1998, 12, 729742.

4 L. U. Thompson, B. A. Boucher, Z. Liu, M. Cotterchio and N. Kreiger, Nutr. Cancer, 2006, 54, 184-201.

5 E. Dornstauder, E. Jisa, I. Unterrieder, L. Krenn, W. Kubelka and A. Jungbauer, J. Steroid Biochem. Mol. Biol., 2001, 78, 67-75.

6 P. Delmonte and J. I. Rader, J. AOAC Int., 2006, 89, 11381146.

7 R. Tsao, Y. Papadopoulos, R. Yang, J. C. Young and K. McRae, J. Agric. Food Chem., 2006, 54, 5797-5805.

8 Q. Wu, M. Wang and J. E. Simon, J. Chromatogr. A, 2003, 1016, 195-209.

9 A. Cassidy, P. Albertazzi, N. Lise, I. W. Hall, G. Williamson, I. Tetens, S. Atkins, H. Cross, Y. Manios, A. Wolk, C. Steiner and F. Branca, Proc. Nutr. Soc., 2006, 65, 76-92.

10 W. Wuttke, H. Jarry and D. Seidlova-Wuttke, Ageing Res. Rev., 2007, 6, 150-188.

11 S. M. Mense, T. K. Hei, R. K. Ganju and H. K. Bhat, Environ. Health Perspect., 2008, 116, 426-433.

12 BfR, Federal Institute for Risk Assessment (BfR), http:// www.bfr.bund.de/cm/349/isolated_isoflavones_are_not_ without_risk.pdf, 2007. 
13 EFSA, European Food Safety Authority (EFSA), EFSA J., 2011, 9, 2264, http:/www.efsa.europa.eu/en/efsajournal/ doc/2264.pdf.

14 EFSA, European Food Safety Authority (EFSA), EFSA J., 2012, 10, 2847, http:/www.efsa.europa.eu/de/efsajournal/ doc/2847.pdf.

15 A. Jacobs, U. Wegewitz, C. Sommerfeld, R. Grossklaus and A. Lampen, Mol. Nutr. Food Res., 2009, 53, 10841097.

16 A. Mortensen, S. E. Kulling, H. Schwartz, I. Rowland, C. E. Ruefer, G. Rimbach, A. Cassidy, P. Magee, J. Millar, W. L. Hall, B. F. Kramer, I. K. Sorensen and G. Sontag, Mol. Nutr. Food Res., 2009, 53(Suppl. 2), S266-S309.

17 R. Chua, K. Anderson, J. Chen and M. Hu, J. Altern. Complement. Med., 2004, 10, 1053-1060.

18 G. Fiechter, B. Raba, A. Jungmayr and H. K. Mayer, Anal. Chim. Acta, 2010, 672, 72-78.

19 K. D. Setchell, N. M. Brown, P. Desai, L. Zimmer-Nechemias, B. E. Wolfe, W. T. Brashear, A. S. Kirschner, A. Cassidy and J. E. Heubi, J. Nutr., 2001, 131, 1362S-1375S.

20 S. Vergne, C. Bennetau-Pelissero, V. Lamothe, P. Chantre, M. Potier, J. Asselineau, P. Perez, M. Durand, N. Moore and P. Sauvant, Br. J. Nutr., 2008, 99, 333-344.

21 I. M. Almeida, F. Rodrigues, B. Sarmento, R. C. Alves and M. B. Oliveira, Food Funct., 2015, 6, 938-946.

22 C. Agostoni, I. Axelsson, O. Goulet, B. Koletzko, K. F. Michaelsen, J. Puntis, D. Rieu, J. Rigo, R. Shamir, H. Szajewska and D. Turck, J. Pediatr. Gastroenterol. Nutr., 2006, 42, 352-361.

23 S. Andres, K. Abraham, K. E. Appel and A. Lampen, Crit. Rev. Toxicol., 2011, 41, 463-506.

24 S. Andres and A. Lampen, Bundesgesundheitsblatt Gesundheitsforschung Gesundheitsschutz, 2013, 56, 277-284.

25 Y. H. Ju, K. F. Allred, C. D. Allred and W. G. Helferich, Carcinogenesis, 2006, 27, 1292-1299.
26 Y. H. Ju, J. Fultz, K. F. Allred, D. R. Doerge and W. G. Helferich, Carcinogenesis, 2006, 27, 856-863.

27 T. T. Rajah, N. Du, N. Drews and R. Cohn, Pharmacology, 2009, 84, 68-73.

28 A. M. Sotoca, D. Ratman, P. van der Saag, A. Strom, J. A. Gustafsson, J. Vervoort, I. M. Rietjens and A. J. Murk, J. Steroid Biochem. Mol. Biol., 2008, 112, 171-178.

29 W. Seinen, J. G. Lemmen, R. H. Pieters, E. M. Verbruggen and B. van der Burg, Toxicol. Lett., 1999, 111, 161168.

30 J. W. Erdman, Jr., T. M. Badger, J. W. Lampe, K. D. Setchell and M. Messina, J. Nutr., 2004, 134, 1229S-1233S.

31 C. S. Hwang, H. S. Kwak, H. J. Lim, S. H. Lee, Y. S. Kang, T. B. Choe, H. G. Hur and K. O. Han, J. Steroid Biochem. Mol. Biol., 2006, 101, 246-253.

32 A. Escande, A. Pillon, N. Servant, J. P. Cravedi, F. Larrea, P. Muhn, J. C. Nicolas, V. Cavailles and P. Balaguer, Biochem. Pharmacol., 2006, 71, 1459-1469.

33 A. Romani, P. Vignolini, A. Tanini, B. Pampaloni and D. Heimler, Nat. Prod. Commun., 2010, 5, 1775-1780.

34 A. Pfitscher, E. Reiter and A. Jungbauer, J. Steroid Biochem. Mol. Biol., 2008, 112, 87-94.

35 K. Morito, T. Hirose, J. Kinjo, T. Hirakawa, M. Okawa, T. Nohara, S. Ogawa, S. Inoue, M. Muramatsu and Y. Masamune, Biol. Pharm. Bull., 2001, 24, 351-356.

36 J. G. Berrin, W. R. McLauchlan, P. Needs, G. Williamson, A. Puigserver, P. A. Kroon and N. Juge, Eur. J. Biochem., 2002, 269, 249-258.

37 H. Matern, H. Boermans, F. Lottspeich and S. Matern, J. Biol. Chem., 2001, 276, 37929-37933.

38 M. Behr, J. Oehlmann and M. Wagner, Food Chem. Toxicol., 2011, 49, 2681-2688.

39 O. Ortmann and C. Lattrich, Dtsch. Arztebl. Int., 2012, 109, 316-323. 